\title{
Across Boundaries: The Global Challenges Facing Workers and Employment Research
}

\author{
Gregory Jackson \\ Freie Universität \\ Sarosh Kuruvilla \\ ILR School, Cornell University \\ Carola Frege \\ London School of Economics
}

\begin{abstract}
The overall complexity of employment relations today raises new challenges for scholars to extend their work across the boundaries of particular geographies, organizations, theoretical perspectives and disciplines. To celebrate the $50^{\text {th }}$ anniversary of the British Journal of Industrial Relations, this article introduces key aspects of global challenges facing employees and research on employment relations. Drawing on the articles of this anniversary issue, we identify several theoretical concepts drawn from the wider social sciences that have proven useful in understanding global challenges around global value chains, transnational and multi-level institutional frameworks, and the role of global finance. We also identify and discuss the emergence of new actors that have a growing salience for global employment research and the establishment of more global forms of worker representation. By further developing theoretical concepts around these global challenges, we argue that employment relations research will increase its dialogue with and distinctive contribution to wider debates in the social sciences.
\end{abstract}

\section{Introduction}

In the editorial of the inaugural issue of the BJIR in 1963, founding editor Ben Roberts noted that the object of the journal is to 'promote a better understanding of the nature of problems that are complex, shifting and difficult to resolve successfully' and that 'great importance is attached by the editors to studies of a comparative nature'. Indeed, the lead article in the inaugural issue was devoted to an 
analysis of social and labour policy in the European Community, and half the issue was devoted to international topics. Our call for articles for the 50th anniversary issue was completely consistent with this early editorial, in its focus on new theory and policy with regard to the current complex global challenges facing workers and employment relations (ER) research.

The call for articles resulted in a conference held at the London School of Economics on 13-14 December 2011 and over 50 submissions for the $50^{\text {th }}$ anniversary issue. The eight articles that made it through the review process exhibit varying foci, from new theoretical lenses for the field, a preoccupation with new actors and new institutions at a supranational level, interdependencies between these actors and institutions, and examples of new solutions with regard to the global challenges facing workers. This 50th anniversary issue presents a variety of new perspectives drawing on theories from other social science fields, while exhibiting the BJIR's traditional focus on interdisciplinary, policy-oriented and applied empirical research.

\section{Crossing boundaries}

The anniversary articles are tied together by a common overarching focus - namely, a concern with the overall complexity of ER today, and the need to go across the boundaries of particular geographies, organizations, theoretical perspectives and disciplines. Indeed, the changing practical and scholarly boundaries of ER pose both new challenges, as well as opportunities for scholarly innovation and theoretical contributions. Engaging with these boundaries, we feel, will help increase the relevance of ER scholarship as well as its impact on other fields of study.

From a theoretical standpoint, globalization has raised questions about the efficacy of traditional theories of ER. In the 55 years since Dunlop (1958) published the international relations (IR) system and 25 years since Kochan et al. (1986) wrote their 'transformation book', many ER theories remain bounded and embedded in the national historical context (Hyman 2001), even if ER scholarship grew more comparative in its focus. For example, comparative ER scholars have highlighted how globalization has affected different sectors and groups of workers, resulting in a growing diversity in patterns of industrial relations within nations, as well as a growing convergence of such patterns across nations (Katz and Darbishire 2000; Locke et al. 1995). Similarly, the effects of globalization on ER systems has been well studied (Frenkel and Kuruvilla 2002), and the response of labour unions to globalization has been of interest, particularly in the burgeoning literature on union revitalization (Findlay and Warhurst 2011; Frege and Kelly 2003; Saundry et al. 2012; Turner 2005) or transnational 
unionism (Gumbrell- McCormick 2013; Keller and Werner 2012; Meardi 2012; Niforou 2012). Thus, even though comparative ER scholars have grappled with globalization's effects, their frameworks and theories have centred on individual actors embedded in distinct national institutional contexts, and the impacts of these national contexts on firm strategies.

Globalization brings a heightened complexity in terms of the connections between different types of actors across a variety of national contexts, and the interdependent effects of their strategic actions across a wider geographic scope. Consequently, addressing global challenges for ER requires new theoretical tools and frameworks to address these new interdependencies. Here, there is significant inspiration to be drawn from other disciplines. International business studies scholars have developed theories of multinational enterprise (Guillen and Garcia-Canal 2009), and these have been increasingly applied to study employment in multinationals (Marginson et al. 2010). Sociologists have articulated global value chain (GVC) theory (Gereffi and Korzeniewicz 1994) and have used network analysis to better understand phenomena occurring across the boundaries of multiple organizations (Podolny 2001; Powell 1991; Whitford 2005), and geographically dispersed social groups. Comparative political economy scholars have extensively studied different national systems of innovation and the different roles of human capital within them (Hall and Soskice 2001; Whitley 1999, 2007). Corporate governance scholars have documented the role of labour within corporate governance (Aguilera and Jackson 2003), as well as how changes in ownership and finance influence ER (Gospel and Pendleton 2005). Geographers have articulated the global production network theory to examine power and value in global production networks (e.g. Coe et al. 2008). Political scientists have stressed the emergence of multi-level polities beyond the national state, such as the EU, that constrain the ability of politics to shape the regulation of labour or the welfare state in new ways (Höpner et al. 2009; Scharpf 2010). Political economy scholars have focused on new transnational modes of governance based on self-regulatory codes and soft law (Djelic and Quack 2003), such as corporate social responsibility or social branding initiatives (Campbell 2007; Fransen 2012; Gjoberg 2009; Matten and Moon 2007; Vogel 2006). New literature on social movements (Davis et al. 2005) points to new forms of internationalization by labour movements and coalitions between labour and wider parts of civil society on a global scale.

These are illustrative examples, not an exhaustive list of new theoretical perspectives in the wider social sciences, but they certainly have the potential to inform and advance ER scholarship in this globalized era'. As we shall discuss later, ER scholarship may also help advance these theoretical perspectives by sharpening the focus on the politics of work and concrete dynamics of ER, often missed 
in some more macro-orientated theoretical perspectives. Our hope is that a more comprehensive understanding of the negative impacts of globalization (e.g. employment strategies that commoditize and casualize labour, disintegrate the working class, expand inequalities globally, weaken both union power and state sovereignty) will lead to new policy-relevant conceptions that involve both traditional actors and institutions (national governments, unions, employers) as well as new ones from the transnational domain (e.g. non-governmental organizations (NGOs), global union federations, other multilateral organizations and corporate social responsibility programmes).

\section{Theorizing global challenges}

Consistent with the idea that we must deal with increased complexity to understand the challenges facing workers at a global scale, the articles in this issue offer a variety of new theoretical conceptualizations related to globalization. While the articles in this volume do not address the myriad challenges facing ER, they highlight three types of global interdependencies: the reorganization of production into geographically dispersed global value chains, the emergence of transnational political arenas and the rise of new forms of global investors that play a more active role in the governance of companies. Here, we emphasize briefly how these challenges not only span geographic boundaries, but provide opportunities for ER scholarship to develop and utilize theoretical concepts from other social science disciplines.

A first challenge relates to how the globalization of production influences the situation of workers. Lakhani, Kuruvilla and Avgar build on global value chain theory to introduce a conceptual framework that explicitly addresses the ER implications of the interconnectedness between firms in the global economy. Today, when production and services are increasingly co-ordinated across both countries and firms, global value chain theory suggests that different value chain configurations will have different ER patterns and governance. In particular, lead firms within global supply chains play a critical strategic role here, but in ways often shaped by the national institutions of their home country. On the basis of these institutionally embedded strategies, global firms organize and interact with supplier firms that are often spread across different countries and shaped by a diversity of local institutions. Thus, GVC theory attempts to take into account the institutional diversity between the home and host countries of firms, as well as the strategic elements of their interaction - including the ways in which firms strategically locate production in relation to these institutional factors, such as when firms move production to countries with weak labour rights or seek to avoid such contexts due to 
reputational risks related to labour problems. This perspective contributes to ER scholarship by creating a set of testable propositions and a baseline tool for comparative analysis. In so doing, the authors encourage a shift in the focus of ER scholarship, moving us from firm-based analyses to network-based analyses, as well as away from bounded national institutional contexts and towards the interdependencies between diverse sets of institutions located in different parts of the value chain. As such, the GVC concept has strong potential as a tool for analysis of ER (see also Riisgaard and Hammer 2011).

A second challenge relates to the transnational dimension of politics, particularly how national institutions that govern employment relationships are increasingly embedded within multi-level institutional arrangements that include transnational elements. Keune and Marginson study the emergence of supranational governance arrangements in the global economy using a theoretical lens of multi-level governance and aspects of power relations. They point to the importance of the vertical dimension of increased interdependence between governance mechanisms at different levels (e.g. national level and the EU level in Europe), as well as the horizontal dimension via the growing interdependence between government and non-governmental actors. Using this multi-level governance perspective, their analysis of the European Social Dialogue suggests that implementing autonomous agreements (European-level agreements implemented not through directives, but through national institutions and procedures) depends not only on variable national institutions. The ambiguities in the coupling between national and European levels, as well as the horizontal connections between unions and works council-based structures also play a role. The nature of the outcomes is to a large extent dependent on the power relationships involved. More generally, multi-level theories are important when studying international phenomena and can be used to map the two-directional nature of interactions across levels - both top-down processes and bottom-up dynamics, as well as the horizontal relationships among different actor groups across these levels.

A third challenge relates to the role of finance. Here, the growth of financial markets around the world and the rise of new types of financial investors are exerting new sorts of pressures on workers. Clark, Appelbaum and Batt point to the thus far understudied role of new financial intermediaries and capital market actors that operate globally. Clark et al. contrast the value extraction processes of traditional 'managerial' capitalism (firms that make money through investments in productive enterprises) with those of newer financial capitalism (e.g. private equity firms) on the basis of four diverse case studies of private equity buyouts at Mervyn's (retailer) and Stuyvesant Town/Peter Cooper Village apartment complexes in the USA, as well as EMI Music Corporation and the confectioner 
Cadbury's in the UK. Financial capitalism, in their view, has different modes of value extraction, which breach levels of trust and implicit contracts, often with devastating impact on stakeholders such as workers and unions. While comparative management scholarship has widely assumed that liberal 'varieties of capitalism' were characterized by managerial control and largely dispersed ownership, private equity shows a historical evolution towards a more financialized economic system and a stronger tie to shareholder control. The analysis here provides both a more fine-grained theory of how capital extracts value, as well as showing the global interdependence of financial systems and their effects. The authors argue that this development has wider global implications, also for countries with institutions that traditionally support patient capital and more long-term relational forms of economic coordination. In their analysis, the new financial capital is not constrained by interlocking institutional arrangements of national business systems, but operates globally. A key implication of their analysis is that financial capitalism decisively shifts power to the capitalist class by exacerbating the divergence of interests among owners, middle managers, workers, suppliers and local communities. This suggests a rich research agenda to see how corporate restructuring and its impact on employees is influenced by changes in corporate governance and a growing role of new financial capitalists in different countries. Some recent studies have begun to address how financial capitalists influence labour in different countries with different institutions governing ER (Buchanan et al. 2012; Gospel et al. 2011, 2014).

These three challenges outlined above each represent a distinct and important arena for further study. When looking at them together, we can see that these new forms of global interdependencies all point to the emergence of new types of actors into the analysis of ER - new organizations such as supplier firms and their networks, new political actors at the supranational level or new types of financial investors. As analytical concepts are transposed across social settings or used in comparative analysis of institutional contexts, researchers face an inherent potential of an apples and oranges problem - specifically, the identities and interests of actors, such as business firms or owners, may be non-identical (Locke and Thelen 1995). For example, unions are organized in very different ways based on distinct logics of membership and interest articulation in different countries, and may respond very differently to seemingly similar human resource management (HRM) practices (Godard 2009). Globalization sharpens our awareness of this methodological issue, and makes it more central to theories of ER.

Among new actors, financial investors reflect a very diverse group of hedge funds and private equity investors with different implications for labour (Gospel et al. 2014). But as mentioned above, these actors may have very different identities and therefore follow different sets of ideas and interests 
across institutional contexts since these identities and interests are shaped by or co-constituted by these very social contexts (Jackson 2010). By problematizing the identity and interests of collective actors, ER scholarship may also gain new theoretical insights that enrich or extend the core concepts in the field.

Moreover, new actors on the labour side such as transnational union networks, critical NGOs and civil society groups are becoming key players, their strategies giving rise to new types of institutions (such as European Works Councils (EWC) and Global Union Federations). These institutions are interesting because of how they intersect transnationally and globally. As Keune and Marginson note in their article, 'Transnationalization's effect has been to redraw and increase the complexity of the industrial relations map, adding new levels, new actors and new institutions, and creating new horizontal and vertical relationships and interdependencies between company, sectoral, national, and transnational, public and private actors'. While European integration is a critical case and focus on early research (Grahl and Teague 1992), many concepts and lessons can be extended to other regional integration processes (Kaminska and Visser 2011). Similarly, traditional regulatory models based on national law have given way to more complex modes of 'new governance' based on soft law and principles, which has changed the role of existing actors such as the International Labour Organisation (ILO) within a new set of global institutions (Baccaro and Mele 2012). This increased level of complexity, we argue, is what questions the adequacy of outdated frameworks and theoretical lenses that are rooted in distinct national institutional contexts. This BJIR 50th anniversary issue thus seeks to highlight and advance recent scholarly developments in ER research, with articles attempting to redirect our scholarly attention away from firms and actors in national contexts to networks and interdependencies in a global context. Thus, new global challenges can be used to both enrich and expand our theoretical tools by taking into account the complex interactions and interdependencies between old and new actors, as well as institutions at the global level.

\section{Re-conceptualizing worker representation globally}

While globalization increases the complexity and interdependence of actors in ER, what implications does this have for how solutions to some of the global challenges faced by workers might emerge? Two groups of articles in this 50th anniversary issue deal with different aspects of how worker representation and labour politics operate within the global context. A first theme emphasizes solutions that are found in these new interdependencies among unions and workers at multiple levels, such as transnational union networks, organizing and bargaining at the global level. A second theme highlights solutions at the 
local level, specifically in innovations in organizing and in the interdependencies between public and private regulation at both global and local levels. The notion of multiple levels and expanding interdependencies among actors and institutions are thus at the heart of this issue.

Consistent with the view that global ER regulation involves new interdependencies between actors and institutions, Locke and Rissing highlight the way in which public and private regulation may interact to improve labour and environmental standards through global supply chains. They theorize that the nature of this interaction differs across nations with different degrees and styles of regulatory enforcement. In nations with more active government enforcement, international private regulation of multinational corporations complements government regulatory efforts. However, they argue that in nations with weak enforcement mechanisms, international private regulation serves as a substitute to national efforts. Locke and Rissing's analysis highlights the variation not only across countries, but across issues. Here, private regulation may function as either a complement to existing regulation with regard to some issues or as a substitute for regulation regarding other issues - even within the same country. Their contribution to the scholarly analysis of contemporary labour relations is twofold. First, the authors make progress on understanding the challenges of global value chains as outlined in the article by Lakhani et al. showing how coalitions of actors and bundles of institutions work together to realize improvements in labour conditions. Second, they show the varied ways in which the national context of the host economies matters (on the role of host country institutional diversity, see Jackson and Deeg 2008). This goes beyond some notions of weak states or so-called institutional voids found in international business literature (Khanna and Palepu 2006) by showing the substantial possibilities for effective regulation in these settings. Important here are the specific forms of institutions and roles of informal institutions, as well as local actors, who can support company strategies for promoting stronger labour regulation. In so doing, their work suggests a rich area for future comparative research, that is, how do private and public forms of regulation interact within and across different countries and across different issues (see also Weil and Mallo 2007).

Networks are also a central focus in Fichter and Helfen's conceptualization of new supranational institutional actors, in this case the transnational union network. Highlighting the intersection of emerging transnational union networks with global production networks, the authors argue that labour relations within global production networks are linked to the practices of inter-organizational network governance. This theoretical frame helps specify how characteristics and institutions of particular global production networks influence the policy options and available modes of network governance for emerging transnational union networks. Thus, Fichter and Helfen not only advance our theoretical 
understanding, but provide insight into solutions regarding how the governance of transnational union networks shapes the ability of unions to influence labour conditions and labour relations in global production networks. By conceptualizing the transnational arena of labour relations as multi-level relationships, a better understanding is gained as to how unions institutionalize co-operation within a global setting. Of crucial policy relevance for global union federations is the empirical finding that transnational union networks centred and co-ordinated by Global (or European) Works Councils are easier to establish, but run the risk of 'company syndicalism'. Meanwhile, transnational union networks that seek to link workers from the core and the periphery independently of particular companies, runs into the problem of not being able to build associational union power without substantial resources. The empirical insights raise fundamental questions for global union strategy, particularly of the global union federations.

The interdependencies between actors and institutions at multiple levels are also evident in Dehnen's analysis of contemporary transnational institutions. In terms of vertical and horizontal dimensions of multi-level institutions stressed by Keune and Marginson, Dehnen's analysis of the complex intertwining of EWCs and International Framework Agreements (IFAs) sheds light on the horizontal dimension of negotiation between these institutions.

Her article highlights how the emergence of IFAs at the level of global institutions reflects a complex within-company negotiation process across different levels and geographic locations of the firm. Here, both EWCs and IFAs are co-dependent. EWCs may be able to use IFA negotiations to strengthen themselves, whereas Global Union Federations can also use EWCs as a mechanism to gain access to firms in order to monitor and implement these agreements. Thus, the strength of the global agreement is to some extent influenced by the nature of the European consultative process and provides a nice illustration of the dependencies between these new actors and institutions at new levels of analysis. Like all the preceding articles, Dehnen's analysis also encourages us to look beyond the firm and the country to new institutions and actors at the global level.

These observations made by Dehnen, but also by Fichter and Helfen, can be linked back to a point discussed by previous articles, namely, that the complex network of organizational structure and its boundaries are very important for the articulation and representation of employee interests. Indeed, the boundaries of organizations and strategic decisions regarding what is core or peripheral or what is located in different places have strong influence on strategies for organizing labour. A crucial aspect concerns the strategic decisions about who is inside or outside different sets of structures of interest representation (Doellgast 2012; Sako 2006; Sako and Jackson 2006). These insights have 
implications for other aspects globalization, such as offshoring (Gomez et al. 2013), and how this relates to negotiation and concession bargaining in the workplace and enterprise.

Tapia and Turner focus on innovations in union campaigns directed at a vulnerable group: immigrant workers. Globalization is also associated with a steadily increasing number of immigrants. Unlike the diversity of institutions posed by global value chains, immigration reflects a growing internal diversity in the demographic and cultural composition of the workforce within single institutional environments. The growing heterogeneity, however, may pose different sorts of problems in different countries due to the unique conceptions of citizenship and corresponding forms of economic, social and political rights attached to immigrant groups (Guild et al. 2009). Extending this to problems of union organization, the authors focus specifically on union strategy and show that unions in both UK and France have successfully executed strategies to organize immigrant workers despite very different labour movements, and vastly different institutional contexts for ER. In both cases, the unions used broad, inclusive and flexible frames emphasizing social justice and fairness, stepping out of their traditional comfort zones, and in so doing, enhanced the ability and willingness of immigrant workers to stand up for their rights. While their analysis is consistent with Polanyian style counter movements against a neoliberal global order (Boyer 2011; Gemici 2008), their contribution rests in illustrating that union strategies can often overcome seeming constraints of a specific institutional context. As such, these findings have implications for general understandings of how actors respond strategically to institutions (Oliver 1991), create incremental forms of institutional change (Thelen 2009) and use agency in the form of institutional work (Lawrence et al. 2009).

Perhaps the most uplifting case of success is that of female garment workers in Bangalore, studied by Jenkins. This study is of particular interest given the recent accident in Bangladesh, where the collapse of a factory building in Dhaka killed 1,127 garment workers - 'the worst tragedy in the history of the global garment industry' (Guardian, 14 May 2013). So far, 32 multinational textile companies have signed the 'Bangladesh agreement' supporting better health, safety and working conditions. This could become a turning point in the development of a worldwide, multi-stakeholder approach to global labour standards - including western consumers, multinational companies, international and local unions, the ILO, NGOs, as well local actors and legislators to significantly improve working conditions, ideally not just in Bangladesh but in factories across all developing and transitional economies.

Such a stakeholder network could be strongly linked to local grass-roots activities as Jenkins illustrates. Jenkins' story is an innovative example of grass-roots activism, not by unions but by NGOs, and contains lessons for organizing strategy. Her case illustrates that traditional union organizing 
strategies will not work because women fear harassment by owner managers, face substantial pressure in the workplace and must cope with the fatigue involved in the double burden of factory work and domestic responsibilities. One key lesson is that in order to mount an organizing campaign, activists need to be closely connected with their subjects and thereby understand their lives and difficulties. A second lesson is that it is useful in these instances to think of a 'pre-union concept'. In this case, Jenkins shows that they organized the women for self-help through a micro-savings scheme that spurred collective sentiment, and gradually developed into a union through meetings at workers homes. Although the employers have not yet recognized the union, Jenkins' analysis indicates the importance of a pre-union concept in union organizing.

\section{Revitalizing ER scholarship}

Taken together, the articles in this volume exhibit the efforts of researchers to address the global challenges facing both workers and ER research. The articles succeed in locating some key emerging arenas within global employment dynamics, and also provide new insights and solutions to tackle the growing imbalances and inequalities. They expand our theoretical horizons with lenses that should guide a generation of research to confront the complexities of global ER. At the same time, we hope that these cases illustrate, for practitioners, arenas of success in labour organizing.

The global and interdisciplinary view of ER illustrated by the articles in this volume is absolutely essential in an era where ER scholarship in universities is threatened by declining funding and the closure of industrial relations programmes or the integration of IR departments into business schools. ER scholarship is threatened by the decline of industry and union membership in industrial countries (Piore 2011), but also needs to maintain itself as a vital contributor to debates on globalization. Greater dialogue with issues, concepts and theories drawn from other disciplines might be a viable path to revitalization and making sure the ER tradition sustains its important intellectual contribution as we look ahead." Here, we submit that the contributions of articles in this volume provide at least a hint for a viable future direction. While we argue that ER needs to engage more with other disciplines, we also suggest that the distinctive strengths and perspectives of ER scholarship have the capability to engage and make contributions across disciplinary boundaries to a far greater degree than is presently the case. Not only can ER scholars gain new insights by borrowing concepts and theories from other fields (Oswick et al. 2011), but ER also can and should play a far greater role in these very fields by blending together these concepts and problematizing the assumptions of other disciplines (Alvesson and Sandberg 2011). 
ER scholarship brings a number of distinct strengths to enrich the wider social sciences. Most obviously, ER scholars bring a focus to themes such as work within organizations and the political constitution of business organizations, which are missed in more managerialist strands of business scholarship on strategy, finance or corporate social responsibility. The intellectual origins of ER scholarship have stressed the historical and political context of business and employment, often missed by more universalistic theories of HRM (Martín-Alcázar et al. 2005) or rather 'thin' concepts of institutional context found on international business research (Jackson and Deeg 2008). Finally, ER scholars can demonstrate the continued importance of organized labour as a political actor, sometimes missed in sociology and political science. Indeed, political stability in many countries (emerging as well as advanced) may be influenced by the rising levels of inequality, Thus, new solutions to seemingly very old problem of the 'labour question' will play a major role in shaping the dynamics of global politics in the next 50 years. In sum, the articles in this volume collectively point to new ways forward for ER research. Final version accepted on 15 July 2013.).

\section{Acknowledgements}

The authors thank John Godard and Anja Kirsch for comments on a previous draft. All errors remain our own.

\section{References}

Aguilera, R. V. and Jackson, G. (2003). 'The cross-national diversity of corporate governance: dimensions and determinants'. Academy of Management Review, 28 (3): 447-65.

Alvesson, M. and Sandberg, J. (2011). 'Generating research questions through problematization'. Academy of Management Review, 36: 247-71.

Baccaro, L. and Mele, V. (2012). 'Pathology of path dependency? The ILO and the challenge of new governance'. Industrial \& Labor Relations Review, 65 (2): 195-224.

Boyer, R. (2011). 'Are there laws of motion of capitalism?'. Socio-Economic Review, 9 (1): 59-81.

Buchanan, J., Chai, H. D. and Deakin, S. (2012). Hedge Fund Activism in Japan: The Limits of Shareholder Primacy. Cambridge: Cambridge University Press.

Campbell, J. L. (2007). 'Why would corporations behave in socially responsible ways? An institutional theory of corporate social responsibility'. Academy of Management Review, 32 (3): 946-67.

Coe, N. M., Dicken, P. and Hess, M. (2008). 'Global production networks: realizing the potential'. Journal of Economic Geography, 8 (3): 271-95. 
Davis, G. F., McAdam, D., Scott, W. R. and Zald, M. N. (eds.) (2005). Social Movements and Organization Theory. Cambridge: Cambridge University Press.

Djelic, M.-L. and Quack, S. (eds.) (2003). Globalization and Institutions: Redefining the Economic Rules of the Game. London: Edward Elgar Publishing.

Doellgast, V. L. (2012). Disintegrating Democracy at Work: Labor Unions and the Future of Good Jobs in the Service Economy. Ithaca, NY: ILR Press.

Dunlop, J. T. (1958). Industrial Relations Systems. New York: Holt.

Findlay, P. and Warhurst, C. (2011). 'Union learning funds and trade union revitalization: a new tool in the toolkit?'. British Journal of Industrial Relations, 49: s115-s134.

Fransen, L. (2012). 'Multi-stakeholder governance and voluntary program interactions: legitimation politics in the institutional design of Corporate Social Responsibility'. Socio-Economic Review, 10 (1): 163-92.

Frege, C. M. (2007). Employment Research and State Traditions: A Comparative History of Britain, Germany, and the United States. Oxford and New York: Oxford University Press.

- - and Kelly, J. (2003). 'Union revitalization strategies in comparative perspective'. European Journal of Industrial Relations, 9 (1): 7-24.

Frenkel, S. and Kuruvilla, S. (2002). 'Logics of action, globalization, and changing employment relations in China, India, Malaysia, and the Philippines'. Industrial and Labor Relations Review, 55 (3): 387-412.

Gemici, K. (2008). 'Karl Polanyi and the antinomies of embeddedness'. Socio- Economic Review, 6 (1): 5-33.

Gereffi, G. and Korzeniewicz, M. (eds.) (1994). Commodity Chains and Global Capitalism. Westport, CT: Greenwood Press.

Gjoberg, M. (2009). 'The origin of corporate social responsibility: global forces or national legacies?'. SocioEconomic Review, 7 (4): 605-37.

Godard, J. (2009). 'Institutional environments, work and human resource practices, and unions: Canada versus England'. Industrial and Labor Relations Review, 62 (2): 173-99. 436 British Journal of Industrial Relations

Gomez, R., Gunderson, M. and Morissette, R. (2013). 'Labour adjustment implications of service offshoring: evidence from Canada'. British Journal of Industrial Relations, 51 (1): 148-73.

Gospel, H. and Pendleton, A. (eds.) (2005). Corporate Governance and Labour Management: An International Comparison. Oxford: Oxford University Press.

- - , - Vitols, S. and Wilke, P. (2011). 'New investment funds, restructuring, and labor outcomes: a European perspective'. Corporate Governance: An International Review, 19 (3): 276-89.

- - , - and - - (eds.) (2014). Financialisation, New Investment Funds, and Labour: An International Comparison. Oxford: Oxford University Press.

Grahl, J. and Teague, P. (1992). 'Integration theory and European labour markets'. British Journal of Industrial Relations, 30 (4): 515-27.

Guild, E., Groenendijk, C. A. and Carrera, S. (2009). Illiberal Liberal States: Immigration, 
Citizenship, and Integration in the EU. Farnham, Surrey and Burlington, VT: Ashgate.

Guillen, M. F. and Garcia-Canal, E. (2009). 'The American model of the multinational firm and the "new" multinationals from emerging economies'. Academy of Management Perspectives, 23 (2): 23-35.

Gumbrell-McCormick, R. (2013). 'The International Trade Union Confederation: from two (or more?) identities to one'. British Journal of Industrial Relations, 51 (2): 240-63.

Hall, P. A. and Soskice, D. (eds.) (2001). Varieties of Capitalism: The Institutional Foundations of Comparative Advantage. Oxford: Oxford University Press.

Haworth, N. and Hughes, S. (2003). 'International political economy and industrial relations'. British Journal of Industrial Relations, 41 (4): 665-82.

Höpner, M., Petring, A. and Seikel, D. (2009). 'Liberalisierungspolitik: Eine Bestandsaufnahme von zweieinhalb Dekaden marktschaffender Politik in entwickelten Industrieländern'. MPIfG Discussion Paper 09/7, Köln: Max-Planck- Institut fuer Gesellschaftsforschung.

Hyman, R. (2001). 'Trade union research and cross-national comparison'. European Journal of Industrial Relations, 7 (2): 203-32.

Jackson, G. (2010). 'Actors and institutions'. In G. Morgan, J. Campbell, C. Crouch, O. K. Pedersen and R. Whitley (eds.), The Oxford Handbook of Comparative Institutional Analysis. Oxford: Oxford University Press, pp. 63-86.

- - and Deeg, R. (2008). 'Comparing capitalisms: understanding institutional diversity and its implications for international businesses. Journal of International Business Studies, 39 (4): 540-61.

Kaminska, M. E. and Visser, J. (2011). 'The emergence of industrial relations in regional trade blocks - a comparative analysis'. British Journal of Industrial Relations, 49 (2): 256-81.

Katz, H. C. and Darbishire, O. (2000). Converging Divergences : Worldwide Changes in Employment Systems. Ithaca, NY: ILR Press.

Keller, B. and Werner, F. (2012). 'New forms of employee involvement at European level - the case of the European company (SE)'. British Journal of Industrial Relations, 50 (4): 620-43.

Khanna, T. and Palepu, K. (2006). 'Stategies that fit emerging markets'. Harvard Business Review, 84 (June): 60-9.

Kochan, T. A., Katz, H. C. and McKersie, R. B. (1986). The Transformation of American Industrial Relations. New York: Basic Books.

Lawrence, T. B., Suddaby, R. and Leca, B. (eds.) (2009). Institutional Work: Actors and Agency in Institutional Studies of Organizations. Cambridge: Cambridge University Press.

Locke, R. M. and Thelen, K. (1995). 'Apples and oranges revisited: contextualized comparisons and the study of comparative labor politics'. Politics and Society, 23 (3): 337-67.

- - Kochan, T. A. and Piore, M. J. (1995). Employment Relations in a Changing World Economy. Cambridge, MA: MIT Press. 
Marginson, P., Edwards, P., Edwards, T., Ferner, A. and Tregaskis, O. (2010). 'Employee representation and consultative voice in multinational companies operating in Britain'. British Journal of Industrial Relations, 48 (1): 151-80.

Martín-Alcázar, F., Romero-Fernández, P. M. and Sánchez-Gardey, G. (2005). 'Strategic human resource management: integrating the universalistic, contingent, configurational and contextual perspectives'. International Journal of Human Resource Management, 16 (5): 633-59.

Matten, D. and Moon, J. (2007). "Implicit" and "explicit” CSR - a conceptual framework for a comparative understanding of corporate social responsibility'. Academy of Management Review, 33 (2): 404-24.

Meardi, G. (2012). 'Union immobility? Trade unions and the freedoms of movement in the enlarged EU'. British Journal of Industrial Relations, 50 (1): 99-120.

Niforou, C. (2012). 'International framework agreements and industrial relations governance: global rhetoric versus local realities'. British Journal of Industrial Relations, 50 (2): 352-73.

Oliver, C. (1991). 'Strategic responses to institutional processes'. Academy of Management Review, 16: $145-79$.

Oswick, C., Fleming, P. and Hanlon, G. (2011). 'From borrowing to blending: rethinking the processes of organizational theory building'. Academy of Management Review, 36: 318-37.

Piore, M. J. (2011). 'Whither industrial relations: does it have a future in postindustrial society?'. British Journal of Industrial Relations, 49 (4): 792-801.

Podolny, J. M. (2001). 'Networks as the pipes and prisms of the market'. American Journal of Sociology, 107 (1): 33-60.

Powell, W. W. (1991). 'Neither market nor hierarchy: network forms of organization'. In G. Thompson, J. Frances, R. Levacic and J. Mitchell (eds.), Markets, Hierarchies, and Networks. London: Sage, pp. 265-76.

Riisgaard, L. and Hammer, N. (2011). 'Prospects for labour in global value chains: labour standards in the cut flower and banana industries'. British Journal of Industrial Relations, 49 (1): 168-90.

Sako, M. (2006). Shifting Boundaries of the Firm: Japanese Company - Japanese Labour. Oxford: Oxford University Press.

- - and Jackson, G. (2006). 'Strategy meets institutions: the transformation of management-labor relations at Deutsche Telekom and NTT'. Industrial and Labor Relations Review, 59 (3): 347-66.

Saundry, R., Stuart, M. and Antcliff, V. (2012). 'Social capital and union revitalization: a study of worker networks in the UK audio-visual industries'. British Journal of Industrial Relations, 50 (2): 263-86.

Scharpf, F. W. (2010). 'The asymmetry of European integration, or why the EU cannot be a "social market economy" '. Socio-Economic Review, 8 (2): 211-50.

Thelen, K. (2009). 'Institutional change in advanced political economies'. British Journal of Industrial Relations, 47 (3): 471-98.

Turner, L. (2005). 'From transformation to revitalization: a new research agenda for a contested global economy'. Work \& Occupations, 32 (4): 383-99. 
Vogel, D. (2006). The Market for Virtue. Washington, DC: Brookings Institute.

Weil, D. and Mallo, C. (2007). 'Regulating labour standards via supply chains: combining public/private interventions to improve workplace compliance'. British Journal of Industrial Relations, 45 (4): $791-814$.

Whitford, J. (2005). The New Old Economy: Networks, Institutions and the Organizational Transformation of American Manufacturing. Oxford: Oxford University Press.

Whitley, R. (1999). Divergent Capitalisms: The Social Structuring and Change of Business Systems. Oxford: Oxford University Press.

- - (2007). Business Systems and Organizational Capabilities: The Institutional Structuring of Competitive Competences. Oxford: Oxford University Press.

' 1 . The potential contribution of international political economy to the study of industrial relations, for example, is discussed in detail by Haworth and Hughes (2003).

ii On the disciplinary origins of industrial relations scholarship, see Frege (2007). 